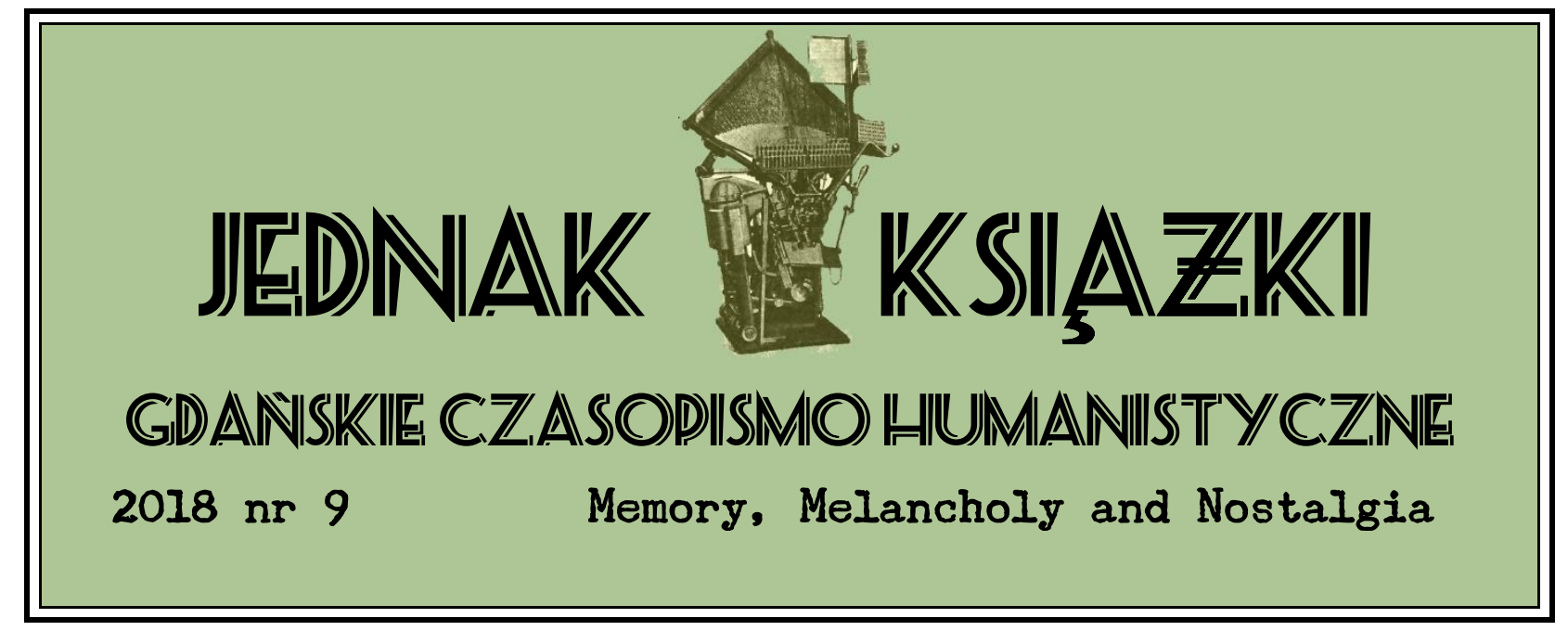

\title{
STUDIESS
}

https://doi.org/10.26881/jk.2018.9.05

\section{WRITING (IN) MELANCHOLY. LOSS AND \\ REMEMBRANCE IN THE WORKS OF TWO \\ CONTEMPORARY HINDI WRITERS}

\section{KAMILA JUNIK-ŁUNIEWSKA}

Jagiellonian University in Cracow (Poland)

Department of South Asia

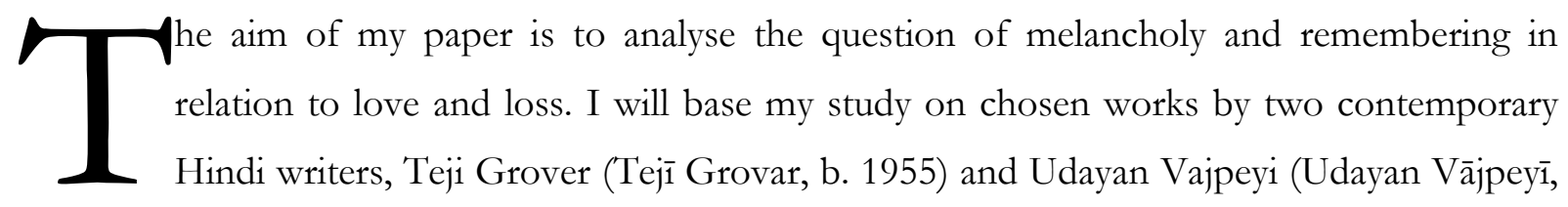

b. 1960). Both writers come from the same generation, and - being a part a new literary movement, Bhopal School ${ }^{1}$ - they represent a similar approach to literature, treating it as means

\footnotetext{
${ }^{1}$ It is worth stating that Hindi literature entered into a modern era in the $20^{\text {th }}$ century and developed its modern idiom (and introduced previously unknown genres like novel) in a relatively short time, comparing to Western literature in general. Modern literature reflects primarily the writers' inclination towards experiment and their openness to all sorts of new artistic ideas (both Indian and foreign). The literary dialect changes to the modern, colloquial Hindi Khari Boli, making it easier to express feelings and dilemmas of modern man. In this way, in the
} 
of all sorts of experiments (with genres, syntax, composition, narration, subject etc.). In the works of the members of the School, the author (narrator, subject) speaks most often in the first person. This change of the subject's perspective - from third person's objectivity to first person's subjectivity - brings about a change in the repertoire of undertaken topics, where searching for own identity, for the lost self, and metatextuality gain the highest importance.

The issues connected to the creative process can also be found in the works of these two chosen authors. There are two main motifs present in Grover's and Vajpeyi's writing: love (pyār) and loss (a-bhav), closely linked with each other as well as with the writing process. By analysing them, I will attempt to prove that in the modern Hindi writing melancholy is a consequence of loss, mourning, and remembering/recalling, and as such becomes a productive and creative force, inducing the author (narrator, subject) to write. Literature (be it prose or poetry), or even writing itself, would be the only possible means for the subject to remember the lost object of love, to re-call him/her, but also to re-gain his/her own lost form/structure.

Furthermore, my aim is to show that the subject - immersed in despair and mourning, but also in love for/with the lost object - extends his sorrow and mourning to be able to write. Consequently, remembering the lost object, longing for it, desiring it, become possible only in separation.

1.

Melancholy has been defined by many disciplines, in many terms. Therefore, before turning to Hindi texts, I would refer to a couple of concepts on melancholy, which will be the starting point of this paper.

In her book on Polish modernist poetry, Alina Świeściak made few observations about the development of melancholy as an aesthetic and literary category, defining a specific mood of a text or a subject. Świeściak points out that melancholy evolved from an unequivocal concept (understood as an irrecoverable loss indicated by a set of certain symptoms) into an ambiguous (equivocal) idea, in reference to which it is difficult to delineate the object of the loss (Świeściak 2010: 6). Thus it may not refer to a defined loss but shall be seen as an overall melancholic mood,

second half of the $20^{\text {th }}$ century, we have a kind of artistic polyphony in Hindi literature. Both writers chosen for this analysis represent a new literary movement - the so-called Bhopal School, which is merely an artistic community of audio-visual artists gathered around Bharat Bhavan, a multi-art complex in Bhopal. The movement emerged in the late 70s, making Bhopal one of the most important centres of innovative creativity in India, in 1980s. Bhopal School artists perceive their creative work in terms of an experiment, act of free and unrestrained imagination, a search for new means and forms of expression. Junik-Łuniewska 2015: 49-69. 
a sense of loss, unclear, indefinite, or as a possibility, a challenge, a mission. According to Świeściak, a melancholic writer is a writer of a specific psyche, tuned on experiencing a loss, perceiving the reality and language through this loss, but also recognizing the melancholic bond between the living and the dead, hinting on a romantic relation between the real and the lost world (Świeściak 2010:14-15). A melancholic subject experiences this loss (caused by death, separation) as a lack, a breakage in his/her own identity, an empty space which he/she tends to re-fill by remembering the lost object, conceptualizing/visualizing it, to, finally, fill it with narration, with writing (Świeściak 2010:19).

Sanja Bahun introduced another interesting concept, focusing "on the mutual implication of mourning and melancholia", "two phenomena that celebrate incompleteness and rupture" (Bahun 2014: 2). In her opinion, melancholia associated with creativity may be seen as a modernist performing melancholia, and mourning the lost object may have a more anthropological, consoling meaning. Bahun perceives modernist literature as "an alternative mourning rite directed at a specific "climate of loss", one distinguished by "the unusual tendency to give form to the very impossibility to mourn" (Bahun 2014: 8). Such a loss/rupture influences the structure and construction of a literary work, which lingers towards open, undetermined form (as defined e.g. by U. Eco).

2.

The feeling of nostalgia, of longing for something undefined, lost and not to be regained, is a concept which can be found in works of contemporary Hindi authors, also of the writers I chose for my analysis. In case of these writers, melancholy, sadness, and nostalgia originate from a real loss, death, however, in a more philosophical sense, it might be interpreted as a loss of love, of the self, as a longing for the very idea of love.

The nostalgic search for own identity, for the feeling of the lost 'wholeness', for the lost self, is clearly visible in Teji Grover's novel Blue (Nila). The book's literary genre is unclear - it meets the criteria of a few genres, e.g. nowveau roman, autobiographical fiction, auto-fiction. There are traces of similarities between the narrator/subject of the text and the author (especially in the mother and father figures) - I use the term "traces" intentionally because the autobiographical facts are hidden, fictionalized, metaphorized ${ }^{2}$. It can be assumed that the Blue's subject functions

2 As an example I shall quote two fragments depicting the father: „He used to live in nineteenth century Russia. His home was nowhere else. Because of nineteenth century Russia he used to visit with oceans of snow and sand." (Grover 2000:55) „...father was always where Nastasya used to flee from blue to brown to blue. (...) In any case, 
on three levels: it is the text's narrator, one of the characters, but it may also be seen as the "inner" author, the writing persona, textual alter ego of the actual author who fictionalizes her own experiences. The subject's identity is unstable; it reveals a breakage, a rupture caused by a loss/lack. It may be the lack of a father, a beloved, but also of the own firm "I-dentity", of knowledge about the self and the world. The story opens with the following fragment:

I know nothing, I know nothing about the blue in Blue Eyes Black Hair. And you will call your eyes blue eyes? Yes, my eyes are blue.

I know nothing about blue.

Neither about brown. But not like I don't know about blue. The relation this has with not writing, not being able to write - that is an old story about my business with blue. But at the moment I'm very tired.

My hair, too, is blue these days. Some of my books. In the empty air of the street, replicas of Blue are streaming toward me one after the other. (...)

I am blue in the coils of this day. I will continue to be blue. One day I will cease to be. Continuing to appear blue even then, I will cease to be. I breathe only to organize blue. At the very last minute I surface from the water to breathe. My hands burn on the stove. I save my hands from turning to ashes. (...)

In this blue, in this invisibility, he weaves me for himself in such way that I don't have an age, a form. In this blue, I could be anything from his writer's block to his twelfth century Russian princess sister. (Grover 2000: 54)

The first lines of the book introduce us to a love triangle between the narrator (subject), Blue, and Brown. All relations in the novel are based primarily on love: paternal, platonic, physical, spiritual. Love is, on the one hand, a metaphor, the first impulse ordering the characters to write (all of them, beside the mother, are writers). On the other hand, love refers to want and desire. As Wiktor Werner stated, love exists only as a metaphor, so it belongs to the symbolic order, to language (Werner 2008: 67). Since love may be expressed through a metaphor, it needs to be written in order to be experienced - just like it happens in the novel. The love-relations of the subject - no matter what kind of love we speak of - become present in the text, become part of reality through the text. In this way love - like Blue, who is a character, but also a colour, prevailing in the text, overwhelming the text and occupying the mind of the narrator/subject - is necessary for the writing to happen, but at the same time this writing becomes the only way for this love to be expressed and experienced. The narrator is madly in love with Blue - her lover,

father used to bury his writing in wooden chests. Father used to write for the termites. (...) I used to weep in Nastasya's blue to Nastasya's brown to Nastasya's blue, and father used to meet me there sometimes. (Grover 2000: 60-61).I quote from an English translation of the novel, published in fragments in 2000 by Meena Arora Nayak. All translations from Udayan Vajpeyi's work are mine and were not previously published. 
who becomes Blue in the novel. She desires to unite with him; she sees the world through love - through the blue colour. There is no other colour in her life: Blue/blue (love, desire) has overtaken her view, has become her obsession. The moments of separation with the beloved make her weep for him, long for him in despair. Psychoanalysts Kakar and Ross compare such mad love with hunger, with pain, which is difficult to extinguish. Referring to mythology - both European and Indian - they remind us of the fact, that it is impossible to unite with the object of our love, that it is natural for humans to long for their complimentary part, and that dualism - and the lack - are attributed to humanity, just like longing is to love ${ }^{3}$.

There is, however, a paradox between desire and longing: desire can be satisfied by (physical) dominance over the object, longing makes the object immortal, indestructible. Longing is associated with the absence of the object: one desires what does not exist, which is not present, whose lack one perceives. Kakar and Ross relate this lack with loss and mourning: "inevitably, however, all passionate love is built on a trembling foundation of loss and depression" (Kakar, Ross 1999: 213). Lovers want to unite, they grieve for each other, but in reality, the spiritual connection is impossible because of the carnality dimension. Yet, as Elżbieta Neyman claims, lovers do not desire a union with the object of their love, but they desire to keep the beloved at a distance and to enjoy the state of separation:

For it is love what they need, not women. Is not love the strongest stimulus of expression, therefore, the greatest source of inspiration? Especially when it takes the form of passion - of love forever inexhaustible, eternally unfulfilled (Neyman 2001: 57).

The absent beloved, for whom the narrator of Blue longs, becomes an impulse to act, to write. He is an idealized image, a mirage, attainable (loveable) in writing, through writing. His absence becomes non-existence/non-presence - abhāv (in Hindi: a-bhāv is the antonym of bhāv - existence, being). Thus it may be metaphorically seen as a trace of an absent presence, as an empty space left after someone else's existence. And this empty space fills with writing. In the words of Maurice Blanchot:

the desire that carries Orpheus forward, and that compels Tristan, is not an impetus able to clear the interval and pass over absence, even the absence of death. Desire is separation itself become that which attracts: an interval become sensible, an absence that turns back into presence. Desire is this turning back when in the depth of night, when everything has disappeared, disappearance becomes the density of the shadow that makes flesh more present, and makes this presence more heavy and more strange, without name and without

\footnotetext{
${ }^{3}$ Kakar and Ross refer to the Plato's myth about the two-headed man with eight limbs, who split into a man and a women, but also to the lonely Purusha from the Upanishads who divided himself into two, guided by the desire. Cf. Kakar, Ross 1999: 201-202.
} 
form; a presence one cannot then call either living or dead, but out of which everything equivocal about desire draws its truth (Blanchot 2003: 188).

In Blue, however, the desire (want and longing) is not directed exclusively toward the lover. Alongside the beloved there is also the figure of the father: lost, absent, and re-presented in the text. The father is the lost object, whose loss at an early age affects the narrator's (author's?) relationships in her adulthood. As Fromm puts it, "Father is the one who teaches the child, who shows him the road into the world" (Fromm 2008: 39). In case of the Blue's narrator, this road was largely the literature, which forms the link between the daughter and the father. Now, through writing, the narrator tries to deal with the mourning for her father, but also to get closer to him. In writing, she brings back to life her own image of the father, her memories of him - since, as Bogna Choińska stated, we "love' only ideas, our own fantasies, not the other person" (Choińska 2011: 150). The subject/narrator - rethinking and remembering what no longer exists - grasps its image, a memory of the loved one. This is when, borrowing the metaphor of Lukasz Mokrosiński, "her life loses the variety of colors" (Mokrosiński 2009: 2) and her story takes only one colour - blue.

3.

The subject in the poems of Udayan Vajpeyi also has a multi-dimensional construction - it refers to the textual as well as to the real world, through biographical connotations. The poet's mourning for his dead wife is not only fictionally present in his own works, but it is also metaphorically interwoven in Grover's novel - creating a link between these two authors and their work in the context of melancholy. In Blue, Udayan, one of the protagonists, always appears in the context of weeping. These fragments can be interpreted in two ways: firstly, as an obvious allusion to the mythological story about king Udayan who lost his beloved queen, Vasavadatta ${ }^{4}$, and secondly - as a reference to the poet Udayan Vajpeyi, who lost his beloved.

The first interpretation alludes to the story of Vasavadatta, who decides to abandon her beloved king allowing him to make the necessary political move and marry someone else. She is officially said to have died in a fire, but in reality, she is still around, living as a maid. King Udayan, although he is married for the second time, still recalls his absent beloved, dreams of her. He sinks in despair and in the desire to see her again. Once, Vasavadatta - driven by longing

\footnotetext{
4 The story of Udayan and Vasavadatta appears in a classical Sanskrit drama Svapnavasavadattā (The Dream of Vasavadatta) composed around $300 \mathrm{BC}$ by Bhāsa.
} 
- approaches him while he is asleep and he, without waking up, talks with her, but later considers it only a dream.

The second way of reading allows for an association of Udayan from Grover's Blue with the poet Udayan Vajpeyi who tries to re-capture the lost presence of his beloved in/through writing. Udayan - in the novel, but also in his own writing - appears as a person immersed in despair, but also in the very idea of love, the object of which he has lost. On the one hand, he is quiet, almost stoic, his weeping is silent, as he would be somehow separate from desire, from carnality. On the other hand, he is suffering his loss by remembering it, as if he would sustain his mourning and sorrow to be able to write: write (about) this sadness, this desperation, this loss. As Freud stated,

serious mourning, the reaction to the loss of a loved one, contains the same (as melancholy - KJL) painful mood, the loss of interest in the outside world - except as it recalls the deceased - the loss of ability to choose any new love-object - which would mean replacing the mourned one - turning away from any task that is not related to the memory of the deceased. (...) it (melancholy - KJL) too may be a reaction to the loss of a beloved object; when other causes are present, it may be possible to recognize that the loss is more notional in nature. The object may not really have died, for example, but may instead have been lost as a love -object (Freud 2008: 74, 76).

The loss of the object of love does not cause the loss of love. Both being in love and/or suffering (crying, weeping, mourning) result in longing for the absent and the desire to re-present it in the language, through writing.

Udayan Vajpeyi dedicated a series of poems by the name Kuch Väky (Some phrases) to his dead wife. But the shadows of the dead - his wife, his father - appear in many of his poems, not just in those from this particular series. The poetry is accompanied by abstract pictures - black and white visualisations that increase the dark atmosphere of the poems. The textual space is fragmentary, scrappy. Just like the attached photographs - showing their objects only partially, cut out from the wider context - they give an impression of peeping through a keyhole into the abyss of memory, where imaginary objects become seemingly real. As in this prose poem:

She dwells in my non-presence (a-bhāv). A blind man, crossing the street, walks into darkness dispersed in front of him like sand. In a hospital's room a young girl stands beside her dying father's bed, she covers her mother's head with her sari, trying to save her beloved. She bends towards me and says: "Keep sitting at the window. I'll be watching you while wandering in the sky. Have you been watching it today?" Mild blueness is pouring off the sky, cascading down through the subtle fibres.

Death hesitates a moment at her dressing room's door, then settles down in her body (Vajpeyī 1995: 119). 
For the writer/subject, his peeping would be in some ways equal to staring into a mirror: in an attempt to see one's own shape or the shape of the lost beloved. In the introduction to the volume the author writes: "Some phrases, I do not know why, cling to each other. My role in this process is not to refrain them from it" (Vajpeyī1995: 7). Earlier in the same passage, he confides:

When I read again these structures (...), I see my own form emerging from them, slightly different, stranger, as something I certainly did not mean while writing (...) Perhaps poetry is just an observation of a different kind (Vajpeȳ̄1995: 7).

The author himself defines his writing process as "indisputable proof (...) of love" (Vajpeyī 1995: 7).

In his poems, Udayan Vajpeyi creates a world in which she - the lost love - exists, where his dead father lives, where it is possible to talk with them, be with them. Mourning and despair are being worked through in a creative way. The oneiric and illusory nature of this world is being indicated by the recurring motif of bed, sleep. Structurally the poems, as the one already quoted, are mainly fragments of prose, with dialogues interwoven into them. Very often she is the subject, she speaks in them - in this way the poet revives her, remembers her. This dialogue between the writer and his beloved may remind us of the dream-like conversation of mythical Udayan and Vasavadatta, which happens not in a half-dream but in the textual space:

She speaks

plucking grammatical errors

from his phrases

she's arranging them into a strange collection

in silence

Now - nobody knows when - the sun will rise

Now - nobody knows when - through invisible fibers of sleep

She will peep out and read

Uttering in the sky's solitude

A love-phrase! (Vajpeȳ̄1995: 68) 
Lost forever, she returns in the creative process - and for the poet, the writing becomes an exchange of letters with his beloved. She reads them very carefully, sometimes adding an answer. In the poet's words,

I give her a phrase to appear

She gives me a space to disappear (Vajpeyī 1995: 120)

This writing is like the journey of Orpheus tracing his beloved. In the words of Maurice Blanchot, "writing begins with the gaze of Orpheus" (Blanchot 1989: 176) - it becomes the only way to keep the loved one close, at the same time condemning her to eternal oblivion. The desire for seizing the other, for fulfilment in love (or writing), is deeply connected with a lack, the loss of the desired object. The object remains desired only when it is elusive, unfeasible:

Dissolving gradually in the sky

The moon

Disappears entirely

In the darkness

In an empty house, for an unknown stretch of time

A child remains hidden behind a table

Hoping to be found

She stands on a rooftop, watching

A glowing window of a distant house

And thinks:

Love is eternal separation (Vajpeyī1995: 73)

And this "eternal separation" is where the need for writing arises. 


\section{4.}

In my analysis of the question of melancholy and remembering in relation to love and loss, two motifs present in the writing of the two chosen Hindi authors, I tried to show, how the mourning for the lost object of love - which drives the subject into despair, depression, and melancholy - becomes a creative force. In contemporary literature, in which the subject's identity is unstable, changeable, writing might be the only constant thing, giving the subject a shelter, a place to be. In a way, melancholia can have a therapeutic meaning, allowing the subject to self-integrate ${ }^{5}$. A rupture, which in the case of the analyzed writers should be seen as a twofold lack, causes the instability of the subject and its melancholy: as a result of the absence of the Lacanian mother, but also as the absence of the beloved. Such absence results from a real loss (death), but also from the inability to be with another person, impossibility to unite with the object of love who always remains a separate being. Thus, love (desire) per se inspires the subject to write, moves him/her into the textual space where the distance between him/her and the lost object decreases. At the same time, this distance is never to be diminished, but in this way, it remains the ultimate condition for the writing to happen.

\section{ACKNOWLEDGEMENTS}

All articles published in the issue are the revised texts based on lectures delivered at the $4^{\text {th }}$ International Interdisciplinary Memory Conference in Gdansk "Memory, Melancholy and Nostalgia” (17-18 Semptember, 2015).

SUMMARY

\section{Writing (in) melancholy. Loss and remembrance in the works of two contemporary Hindi writers}

The paper aims at analysing the question of melancholy and memory in contemporary Hindi literature. The author selected works by two Hindi writers (T. Grover and U. Vajpeyi), who

\footnotetext{
${ }^{5}$ Kristeva 1992: 19-20, Świeściak 2010: 17.
} 
represent similar approach towards literature and use similar means of expression. The two main motifs characteristic for their writing - love (pyār) and loss (a-bhāv) - are closely related to the creative process: the loved one is the lost object, the one subjugated to melancholy, who can be remembered through writing. In the light of A. Świeściak's idea of "melancholic subject" and S. Bahun's concept of "performing melancholia", the author discusses ways in which both the writers construct their literary world, inhabit it with loved/absent objects (beloved, father), and mourn their loss. The subject in their writing is both fictional and biographical, so the loss relates to literary as well as real events, becomes multidimensional. In Grover's Blue, the subject's separation with the beloved leads her to realise the loss of her father in childhood, and thus unveils the mourning and melancholy (symbolically represented by blue/Blue). U. Vajpeyi's poems create a space for meeting his lost love, for weeping and remembrance, for exchanging letters (and writing). The results of the present study show that melancholy - as a consequence of loss, mourning, and remembering - becomes a creative force, inducing the author (narrator, subject) to write.

\section{KEYWORDS}

Melancholy, loss, mourning, Teji Grover, Udayan Vajpeyi, Hindi literature

\section{BIBLIOGRAPHY}

Bahun Sanja. 2014. Modernism and Melancholia: Writing as Countermourning. New York: Oxford University Press.

Blanchot Maurice. 1989. Orpheus's Gaze, 171-176. In: Blanchot Maurice. The Space of Literature. Smock Ann, trans. Lincoln-London: University of Nebraska Press.

Blanchot Maurice. 2003. The Infinite Conversation. Hanson Susan, trans. Minneapolis and London: University of Minnesota Press.

Choińska Bogna. 2011. „Le mur du langage’ - samotnosć według Jacques’a Lacana (inność, porozumienie, miłość)." Przestrzenie Teorii 15: 141-153.

Freud Sigmund. 2008. Mourning and Melancholia, 73-94. In: Freud Sigmund. The Future of an Illusion. Underwood J.A, Whiteside Shawn, trans. London: Penguin Books.

Fromm Erich. 2008. The Art Of Love. New York-London: Continuum.

Grovar Tejī. 1999. Nīīà. Naī Dillī: Vānī Prakāśan.

Grover Teji. 2000. "Neela". Nayak Meena Arora, trans. Hindi: Language, Discourse, Writing 
(1/1): 54-75.

Junik-Łuniewska Kamila. 2015. Literatura jako proces pisania. Analiza „Błękitu” Tedźi Grower w świetle przemian współczesnej prozy hindi. Kraków: Księgarnia Akademicka.

Kakar Sudhir, Ross John M. 1999. Tales of Sex, Love and Danger. New Delhi: Oxford University Press.

Kristeva Julia. 1992. Black Sun. Depression and Melancholia, New York: Columbia University Press.

Mokrosiński Łukasz. 2009. „Realne urzeczywistnione - słowo o depresji i melancholii.” Online: http://sinthome.pl/pic/StronaPL/insomnia/LM_melancholia.pdf. Accessed October 22, 2016.

Neyman Elżbieta. 2001. A słowo ciałem się stało, 42-64. In: Nasiłowska Anna ed. Ciało i tekst. Feminizm w literaturoznawstwie - antologia szkiców, Warszawa: Instytut Badań Literackich.

Świeściak Alina. 2010. Melancholia w poezji polskiej po 1989 roku. Kraków: Universitas.

Vajpeyī Udayan. 1995. Kuch vaky. Naī Dillī: Vānī Prakāśan.

Werner Wiktor. 2008. Miłość jako metafora, 67-76. In: Płonka-Syroka Bożena, Radziszewska Janina, Szlagowska Aleksandra, ed. Antropologia miłości tom 1. Miłość kobiety. Wrocław: Oficyna Wydawnicza Arboretum. 